\title{
Status of Techniques Used to Control Moulds in Maize Storage in Africa
}

\author{
Halfane Lehmane1, Rafiatou Ba1, Durand Dah-Nouvlessounon', Haziz Sina1 ${ }^{\circledR}$, Gautier Roko1, \\ Farid T. Bade1, Akim Socohou1, Adolphe Adjanohoun², Lamine Baba-Moussa1*
}

${ }^{1}$ Laboratory of Biology and Molecular Typing in Microbiology, Department of Biochemistry and Cell Biology, Faculty of Sciences and Techniques, University of Abomey-Calavi, Cotonou, Benin

${ }^{2}$ Institut National des Recherches Agricoles du Bénin, Cotonou, Benin

Email: *laminesaid@yahoo.fr

How to cite this paper: Lehmane, H., Ba, R., Dah-Nouvlessounon, D., Sina, H., Roko, G., Bade, F.T., Socohou, A., Adjanohoun, A. and Baba-Moussa, L. (2022) Status of Techniques Used to Control Moulds in Maize Storage in Africa. Agricultural Sciences, 13, 49-64.

https://doi.org/10.4236/as.2022.131005

Received: November 5, 2021

Accepted: January 22, 2022

Published: January 25, 2022

Copyright $\odot 2022$ by author(s) and Scientific Research Publishing Inc. This work is licensed under the Creative Commons Attribution International License (CC BY 4.0).

http://creativecommons.org/licenses/by/4.0/

\begin{abstract}
In Benin, the preservation of maize is a real problem involving important physical and chemical properties losses. Physical losses are due by rodents, pests and insects and chemical losses are mainly due to fungal infection. Several methods, products and practices are used by farmers to overcome these problems. The methods used do not always control the losses caused by fungal infection. The objective of the study was to make a bibliographic synthesis of the impacts induced by the items, practices and methods used to overcome the chemical losses of maize. In the search for information, the library of the Ministry of Agriculture, Livestock and Fisheries was consulted; the archives of the library of the University of Abomey-Calavi and the National Institute of Agricultural Research of Benin were also consulted. Thus, chemicals such as sofagrain, Pyrimiphos-Methyl, Thiamethoxam, Pyrimiphos-Methyl, Permethrin, Deltamethrin, fumigant are used to control physical attacks on maize. Ash and plants species such as neem tree (Azadirachta indica) are generally used for the preservation and storage of maize seeds. In addition, chemicals such as arsenious anhydride and zinc phosphide are used for the preservation of corn. The use of these molecules and chemical products has negative impacts on human health and the environment. Of all the methods used, no treatment is still popularized for the reduction of the chemical losses caused by the fungal infection in corn storage.
\end{abstract}

\section{Keywords}

Impact, Aflatoxins, Cereals, Conservation, Africa

\section{Introduction}

Throughout the world, cereals have always been the main nutritional resource 
for humans and animals. Among these cereals, maize is the most important and most consumed product by more than $98 \%$ of rural households in Africa [1]. It is also the most important component of livestock feed and can be stored all year round. In many African countries, it is a major staple food for most of the population. To ensure the availability for a family's diet over a long period and to secure seed supply for the next season and to avoid anticipated and low-price maize commercialization, storage is the most appropriate method. However, several pests attack stored maize. These include insect pests that cause losses of $30 \%$ to $100 \%$ within few months, moulds that compromise the quality of maize grain, and mammalian rodents that consume and soil the grain [2]. The poor storage conditions of maize in African developing countries in general increase the risks of its contamination by mycotoxins [3]. This contamination can affect agricultural sector production in general and each of the four pillars of food security (availability, access, food quality, and regularity) in particular. Mycotoxins are responsible for acute and fatal intoxication, especially in livestock. African populations are exposed to aflatoxin even before birth [4] [5]. Mycotoxins represent major challenges for global food security systems, health, nutrition and economies, as they are produced during agricultural production, harvesting, transport, storage and food processing [6]. Humans are particularly concerned by the risk of chronic poisoning due to the presence in their diet of traces of some of these contaminants which are genotoxic and carcinogenic [7]. The Food and Agriculture Organization of the United Nations (FAO) estimates that about a quarter of the world's production is contaminated, representing an economic loss of $5 \%$ to $10 \%$. In addition to the economic impact, mycotoxins pose a real public health problem. Carcinogenesis, immnunotoxicity, nephrotoxicity, hepatotoxicity and neurotoxicity constitute the range of harmful effects of fungal toxins [8]. According to Eliasse et al. [8], aflatoxin contamination of the main staple foods, namely maize, groundnuts and sorghum, reaches unacceptable levels for health in many African countries. Studies by Abdellah and Larbi [9] showed that maize is a cereal with a higher risk of infection by mycotoxin-producing fungi than other cereals (barley and wheat). These contaminations are also favored by certain conditions, including high humidity, inadequate drying and storage of crops. In addition, Fandohan et al. [10] revealed the presence of mycotoxins in maize grown in regions of Ghana and Benin. Thus, aflatoxin is a scourge of cereal production in Africa [11] [12] [13] [14]. The main mycotoxins that are closely monitored from a sanitary and economic point of view, in cereal agricultural productions are aflatoxins and ochratoxins produced generally by $A$. flavus and $A$. parasiticus. The methods used to limit the losses of stored corn are the physical means which have been very successful. Biological control and the use of synthetic chemical insecticides are the most widely used. However, these methods have several limitations among which are the habituation of insects and the selection of resistant strains [15], food poisoning compromising human health, environmental pollution and ecological disorders [16]. The proven knowledge of 
the harmful effects of aflatoxin on health, justified, on one hand, by sanitary events linked to the consumption of cereals contaminated by aflatoxin in Africa (contamination of 317 people by aflatoxin after consumption of maize 125 of them died after hospitalization in Kenya) [17] [18], has accentuated the institutional and scientific fight against aflatoxin in cereals in this continent. Despite this political and scientific will, the presence of aflatoxin, sometimes in high doses, is noted in African cereal production to the point that the effectiveness of the control methods employed is questioned [8]. Given the adverse effects of these different control methods, particularly the use of chemicals on human health, other credible alternatives deserve to be explored [19]. The work we propose consists of a general review of the impacts of the use of chemical substances in the control of fungal infection of stored maize in Africa.

\section{Importance of Maize in Africa and Benin}

Maize (Zea mays $L$.) is the most cultivated plant in the world and the first cereal produced ahead of wheat (Triticum aestivum L. subsp. aestivum). The global production of corn in 2013 was 839 million tons, compared to 653 million tons for wheat [20]. It is also one of the most targeted commodities by various agricultural and socio-economic policies. Cultivated in a marginal way in certain regions in the past; it now occupies a place of choice in Africa in general, and particularly in the peasant farms of Benin, where its production has been increasing steadily for several years. It has increased from 230,000 tons in the early 1970 s to more than 1,354,344 tons in 2014 [21] and represents $75 \%$ of the country's cereal production. The yield, has increased from $600 \mathrm{~kg} / \mathrm{ha}$ on average in 1970 to 1.4 $\mathrm{t} / \mathrm{ha}$ in 2009. Maize is the third most important food crop after cassava and yam [22]. In order to ensure food security, the increase in maize production, which has long been the focus of researchers, extension workers and farmers, has brought to light new constraints related to its storage and preservation. The dominant position of maize in Africa in has been favored by its capacity to adapt to agro-ecological conditions and by its strategic roles as both a cash crop and a high consumption product in many countries [23]. Indeed, the demand for maize on the Beninese market has never been met due to its high demand, high population growth and agricultural policies supporting a high level of cotton's planting. Finally, the diversity of maize consumption forms makes it more attractive [24]. In Côte d'Ivoire, Benin and most Western African countries, maize is the staple diet of rural populations in various forms: fresh, roasted combined with groundnuts, flour, etc. It is also used for the preparation of other foods such as dough, porridge, akassa (cooked starch), cake, etc. [25]. In summary, maize is a multifunctional crop for households in northern Benin [24].

\section{Techniques Used and Difficulties for Maize Conservation in Africa and Benin}

In Benin, maize plays an important role in agricultural production systems, 
where more than $50 \%$ of the cultivated area is devoted to maize, as well as in the local economy and in feeding the population. Confined to the southern areas for a long time, the production of this cereal has now spread to the northern regions. To this end, it is the subject of important national and regional transactions. More than $85 \%$ of it is used for human consumption in various forms. There is therefore a significant increase in production each year and this increase, due to the diversified use of maize, leads to post-harvest problems. To mitigate post-harvest losses, farmers store their crops in traditional structures depending on the climate, the ethnic groups and socio-economic conditions. These structures are generally rudimentary and not very efficient [26]. Improved granaries made of woven plant materials (mallotus, raffia, bamboo, neem, etc.) and improved enclosed earthen granaries are the different storage structures for maize on the cob and grain [27]. Manuals and guides have been introduced to farmers by organizations such as FAO (Food and Agriculture Organization); APRM (African Peer Review Mechanism); IFDC (International Fertilizer Development Center) in an attempt to reduce post-harvest loss rates to an acceptable level. Despite all the efforts made by these structures, it is clear that producers still use inappropriate preservation techniques such as desiccation, wood ash, palm wine distillate, insecticides, etc. These different techniques have led to a significant reduction in the rate of losses up to $5 \%$ and $1 \%$ for improved bamboo granaries and improved earthen granaries respectively [28]. According to Affognon et al. [29], the adoption rate of these techniques is still low. Moulds are caused by different species of fungi, some of which produce carcinogenic toxins. The most frequently encountered in Benin in maize stocks are Aspergillus spp; Fusarium spp; Penicillium spp (Figures 1(a)-(d)) [2].

\section{Pathologies Related to Mycotoxins}

Mycotoxins are compounds resulting from the secondary metabolism of moulds and have a real toxic potential for humans and animals. Fungal toxins are found as natural contaminants in many foods and feedstuffs such as cereals, offal, fruits, vegetables, forage and dairy products. The most relavant families of mycotoxins in food and health point of view are Aflatoxins, Fumonisins, Ochratoxins, ergot alkaloids, Zearalenone, Patulin and Trichothecenes [30]. Several types of aflatoxins (14 or more) occur in nature, but aflatoxins B1, B2, G1, and G2 are particularly dangerous to humans and animals because they are found in all major food crops. Nevertheless, human exposure is primarily from contaminated nuts, seeds, or their by-products [31]. Mycotoxins in food are, in animals and humans, the cause of harmful biological effects grouped under the term mycotoxicoses. Approximately $25 \%$ of food products are contaminated by fungal toxins. It is estimated that there are between 200,000 and 300,000 species in the mycoflora. There is therefore a great diversity of mycotoxins. From more than 400 mycotoxins identified, only about 30 molecules have worried toxic properties [32]. Some of these toxins are supposed to be carcinogenic or mutagenic, 


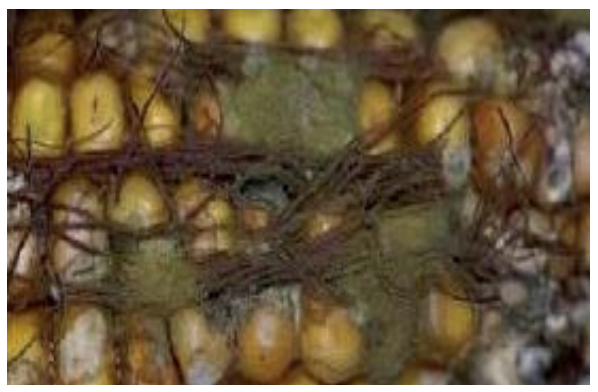

(a)

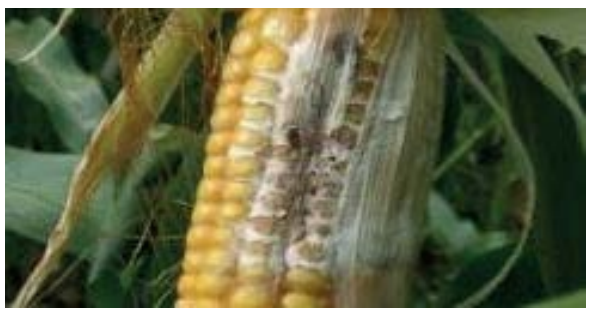

(c)

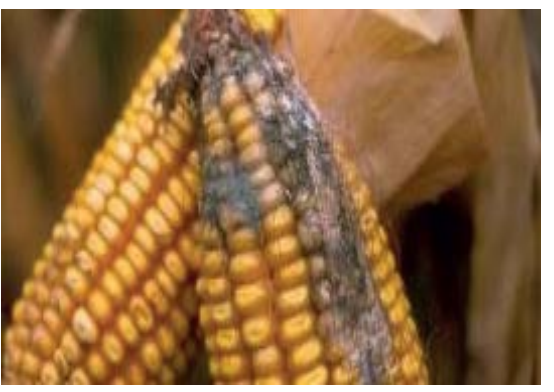

(b)

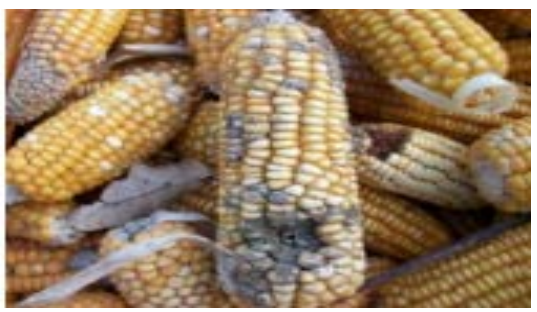

(d)

Figure 1. The main fungi harmful to maize stocks in Benin and their damage. [2]. (a): Poorly dried corn cob covered with olive-green mold caused by the fungus Aspergillus (Iowa State University). (b): No-dry corn cob covered with a blue-green mold caused by the Penicillium fungus (Montpetit Jean-Marc). (c): No-dry corn cob covered with a whitish pink mold caused by Fusarium fungus (Duval Brigitte). (d): Corn cobs contaminated with Aspergillus flavus (http://www.flickr.com).

while others are toxic for the kidneys, the nervous system or the liver. In addition, it should be noted that the toxicity does not necessarily come from the mycotoxin itself, but may be due to one of its metabolites resulting from its degradation. According to their place of production, mycotoxins can be classified into two categories: Field mycotoxins including Fumonisins, mainly produced by the genus Fusarium. The producing fungi develop on senescent or stressed plants. And the mycotoxins of storage of which Citrinin and Patulin which are produced essentially by the genera Penicillium and Aspergillus. The presence of aflatoxin M1 in dairy products is increasingly reported. According to one study, Africa is exposed to toxins that are linked to immune suppression, liver cancer in humans and stunted growth in children. According to UNICEF, $40 \%$ of children in sub-Saharan Africa are stunted or have low height for their age, which may be associated with impaired brain development. Infants and children are particularly affected by aflatoxins, given their still developing defense systems and growing lungs [33]. According to Miller [34], 40\% of maize production is affected by aflatoxins in developing countries. In Benin, frequent consumption of maize increases the risk of aflatoxin contamination. In a study involving children exposed to aflatoxin in Benin, Allomasso et al. [35] showed that there is a positive relationship between aflatoxin and Kwashiorkor (a disease related to malnutrition) which is only a response to nutritional deficiency. According to the same authors, aflatoxin and diarrhea episodes are positively related. Manual 
removal of visibly mouldy, insect-damaged and broken grains reduced aflatoxin content by $40 \%$, according to a study in Benin [10]. In Kenya, aflatoxin contamination of 317 people after consumption of maize resulted in the death of 125 of them after hospitalization [18]. According to Wild [36], hepatocellular carcinoma (HCC) is the most common cancer in men in The Gambia, and the main risk factors for HCC in West Africa are chronic hepatitis B virus infection and aflatoxinfrom all above mentioned, it is necessary to put in place means of control and prevention throughout the food chain, including agronomic strategies (good cultural practices, thoughtful fungicide treatments, choice of crop varieties, etc.), as well as improved harvesting, storage and processing conditions.

\section{Chemical Control}

Fungicides used to treat cereals are either synthetic or organic. Synthetic fungicides are chemical pesticides that have been artificially manufactured to control pests, while organic or natural pesticides contain chemicals made from plants to repel fungi [37]. Synthetic chemicals such as insecticide powders and fumigants are registered in Benin for use on maize grain. The recommended insecticide powders for treating maize in storage are presented in Table 1. According to the MINADER [38], these chemicals require personal protective equipment for application; therefore, they should be applied by professionals or trained personnel and kept away from waterways. In Benin, in a large number of cases, the use of fungicides reaches an unacceptable, uneconomical and unsustainable level. The wide availability of cheap fungicides has often led to overuse and dependence on chemicals. This has resulted in the neglect of traditional plants, and treatment techniques that are available for safe storage at the household level. Among the solutions, some chemical have been found to inhibit aflatoxin production by inhibiting fungal growth. These include propionic acid $(0.1 \%-0.5 \%)$, ammonia $(0.5 \%)$, coppersulphate $(0.5 \%-1 \%)$ and benzoic acid $(0.1 \%-0.5 \%)$ which completely inhibit the growth of $A$. parasiticus [39]; sodium benzoate has an antimicrobial effect on the growth of Aspergillus niger, Aspergillus flavus and A. fumigatus and the production of aflatoxins in packaged garis $(2 \mathrm{~kg} / \mathrm{pack})$ during storage at room temperature $\left(30^{\circ} \mathrm{C} \pm 2{ }^{\circ} \mathrm{C}\right)$ [40]. Sodium hypochlorite $(0.1 \%-0.5 \%)$ exhibits antifungal property $(68 \%-84 \%)$. Urea $(0.1 \%-0.5 \%)$, citric acid $(0.5 \%)$ and sodium propionate $(0.1 \%-0.5 \%)$ were moderate in inhibiting fungal growth [41]. Wherever possible, the use of chemical fungicides should be curtailed through the promotion of an integrated mold management approach.

Table 1. Recommended dose of insecticides in Benin [2].

\begin{tabular}{ccc}
\hline Insecticide powders & $\begin{array}{c}\text { Recommended rate per } \\
100 \mathrm{~kg} \text { of corn }\end{array}$ & $\begin{array}{c}\text { Duration of } \\
\text { action (months) }\end{array}$ \\
\hline Pyrimiphos-Methyl + Thiamethoxam & $50 \mathrm{~g}$ & 6 \\
Pyrimiphos-Methyl + Perméthrine & $50 \mathrm{~g}$ & 6 \\
Deltamethrin & $150 \mathrm{~g}$ & 6
\end{tabular}




\section{Physical Control}

Physical control consists in exposing insect populations or/and cereals to radiation, extreme temperatures or to a change in the oxygen/carbon dioxide content of their biotope [42] [43]. Initiating warehouse pest control while crops are still in the field minimizes the transfer of primary insect pests from the field to the warehouse. It is based on several methodologies invented and developed (such as washing, drying, grinding, manual sorting, mechanical separation or heat treatment) by producers and/or international organizations. In Benin, the main predatory insects such as the maize weevil, the rice weevil, the great corn borer, the triboliums and the grain beetle are the insects frequently encountered in maize stocks. To prevent the development of corn moulds in stocks, a technique has been implemented [2] which consists to:

- Avoid attacks on corn ears by pests (insects, birds and rodents);

- Separate attacked ears of corn and put them away;

- Harvest on the correct date using good harvesting practices;

- Avoid leaving harvested corn lying around the field;

- Avoid piling up corn on the cob after harvest;

- Dry until kernels become crisp under the tooth before storage;

- Observe good storage practices.

Physical control therefore concerns mechano-therapeutic techniques capable of making stored maize healthy for a long time, but they still have shortcomings that are sometimes linked to their inefficiency or to the resistance of pests. Other physical methods have been tested in Africa and have been effective, such as mechanical crushing in the "Entôler", airtight or controlled atmosphere storage and ionizing irradiation (for physical control of Sitotroga cerealella) [44]. Microwave and ozone treatments (ozonation) are also recommended for the detoxification of aflatoxin from contaminated food [45].

\section{Consequences of Aflatoxin-Contaminated Maize on Humans and Their Environment}

As maize production increases dramatically over the years, special attention must be paid to its storage and preservation by farmers. A study of Busani [46] showed that sub-Saharan Africa loses more than $\$ 450$ million in trade revenue from major staple foods, including maize, each year due to aflatoxin contamination. Aflatoxins are particularly prevalent in Benin. Unfortunately, no recent data are available, but a comprehensive study in the mid-1990s clearly showed that " $35 \%$ of maize in Benin is at risk for human consumption" and that, while the center of the country was the most affected region, all regions were also tested positive to with high levels toxin. Producers in the region experience annual post-harvest losses ranging from $20 \%$ to $50 \%$ after only six months of storage [47]; while traders experience loss levels up to $75 \%$ when no phytosanitary treatment is applied [28]. Consequently, the contamination of cereals by this 
toxin has economic, food and health consequences in almost all African countries. Indeed, not only are poor storage methods and the non-adoption of adequate preservation systems by producers often at the origin of these post-harvest losses, but also, a large part of the agricultural population consumes mouldy products because of their low levels of income, education and other socio-economic factors [5]. This creates serious problems for human health. The world population is predominantly exposed to aflatoxins as the presence of aflatoxin M1 recorded in breast milk in Ghana, Kenya, Nigeria, Sierra Leone, Sudan, Thailand, United Arab Emirates [48] and in umbilical cord blood samples in Ghana, Kenya, Nigeria and Sierra Leone [49]. A study conducted by Gong et al. [50] in Benin and Togo revealed the presence of aflatoxin in the blood of children aged 1 to 3 years whose diet is based on local cereals. The same authors also showed that aflatoxin contamination had a significant negative impact on children's growth with $30 \%-40 \%$ higher concentrations of aflatoxin albumin [51]. The same is true for children aged 4 - 6 months in Kenya [52]. Exposure to aflatoxin in these populations will induce recurrent health problems related to aflatoxicosis [53]. Aflatoxin B1 is a human carcinogen and is one of the most potent contributors to liver cancer known. Human deaths were also caused [54] by acute aflatoxin poisoning in 1974, when unseasonal rains and a food shortage caused the population to consume heavily contaminated maize. Aflatoxins in general have an immunosuppressive effect, so they may reduce resistance to infectious agents (e.g., HIV or tuberculosis) [32].

\section{Traditional Control: Practices and Plants Used for Mycotoxin Reduction in Stored Maize in Africa}

In Africa, the post-harvest losses recorded are not only of physical nature (caused by insects and rodents) but also chemicallosses caused by the presence of mycotoxin-producing moulds. The most toxic mycotoxins, the aflatoxins, are mainly produced by the strains of Aspergillus flavus, A. parasiticus, A. nomius [55], A. pseudotamarius and $A$. bombycis [56]. A. flavus and $A$. pseudotamarius produce mainly AFB1 and AFB2. Aflatoxins, substances naturally produced by some fungi, contaminate many common foodstuffs such as maize, peanuts, rice, and cassava, especially under certain conditions: dry weather near crop maturity, high humidity at harvest, and inadequate drying and storage of crops [57]. But among cereals, maize is more vulnerable to Aspergillus contamination. Mycotoxins are present in a wide range of food and feed products and cause numerous diseases in humans and animals [58] [59]. Up to 4.5 billion people are exposed to aflatoxins, which can cause several diseases such as liver cancer in humans and stunted growth in livestock [60]. According a study by Ahmed et al. [61], among the factors that exacerbate the contamination of cereals by Aspergillus and then by aflatoxin in Africa are over-ripe harvests, delayed drying and damaged grains during dehulling. Also, storage of harvested grains with moisture content $>10 \%$ and for prolonged periods in inadequate facilities leads to the proliferation of 
moulds in the grains. To address this, various techniques have been developed to destroy or suppress mycotoxin toxicity in foods. Scientific research in Africa has found safe natural fungicides such as Lippia multiflora's leaf extract, which has a static fungal effect on Aspergillus flavus and Fusarium verticillioides [62]. Essential oils, ozone, diatomaceous earth and food antioxidants such as butylated hydroxyanisole (BHA), butylated hydroxytoluene (BHT) and propyl paraben (PP) are promising non-toxic cost-effective options that can replace toxic chemical preservatives in the control of various fungi including Aspergillus, Fusarium and Penicillium [63]. A study done in Benin by Ba et al. [64] showed that scopoletin at the dose of $0.024 \mathrm{mM}$ prevented the secretion of aflatoxins in cassava pods. Its content varies from cassava roots to its processing products [65]. Scopoletin has also been isolated from other plant species such as: Aster tataricus and Foeniculum vulgare, the stems of Erycibe obtusifolia Benth which were usually used in traditional Chinese medicine against rheumatic arthritis [66]. It has been identified as the main compound in plants such as Nicotiana glauca, Lycium chinense, Angelica dahurica and the roots of Trigonella foenum-graecum [66]. Dieme et al. [53] showed that some practices include the use of insect resistant varieties such as Cathartus quadricollis and Sitophilus zeamais which play an important role in the contamination of food by toxigenic moulds. Regarding aflatoxins, resistant varieties of maize have been identified and introduced in public and private plant breeding programs [14]. As part of a US-Africa collaborative strategy, the International Institute of Tropical Agriculture (IITA) and the USDA have obtained six pure lines adapted to Africa with improved resistance to aflatoxin accumulation [67]. Furthermore, biological control experiments against aflatoxins using also local strains are underway in Kenya [68] [69] and Nigeria, but at a more advanced stage in the latter country, where maize farmers have managed to reduce aflatoxin contamination by about $80 \%$ [70]. Other study [reference] showed that natural fungicides are generally safer and more environment friendly alternative for mold control home storage, farms and gardens. Because of the frequent adverse effects of synthetic pesticides on the environment and the population, the use of natural insecticides is strongly recommended, especially for small-scale farmers, local communities, schools, and vulnerable segments of the population who are most likely to be not well trained and equipped to use pesticides. Natural insecticides include traditional materials, such as abrasive mineral powders, natural drying agents such as wood ash, plant materials with repellent or insecticidal properties (such as parts of the neem tree, Azadirachta indica) or vegetable cooking oils (palm, groundnut or coconut) [37]. Among the plants whose use has been most often recorded, we cite Hypas spicigera. It is used in the form of powder for the protection of cereals (such as corn) or plastering. Neem (Azadrichita indica) is the most popular and promising plant with insecticidal effect. Extracts of neem and derived products have been manufactured and marketed as insecticides. Other promising materials include "sweet flag" (Acorus calamus), "wormseed" (Chenopodium ambrosioides) and the repellent 
pepper (Piper spp). Other not yet botanically described plants have also been recorded for example the locally called Naplaw in the Dagari of Burkina Faso. The dried and crushed stems and leaves are ground into powder and mixed with ash as a carrier. The application is done in successive layers on sorghum, maize, rice and groundnut stocks [37]. A literature review done in Senegal by Eliasse et al. [8] revealed that a new aflatoxin field control technology is used in Nigeria, Kenya, Senegal and Burkina Faso. This technology named AflaSafe is based on the principle of competitive exclusion that mitigates the negative effects of aflatoxin. It is therefore a $100 \%$ natural product and its use has given promising results on maize in Kenya [71]. AflaSafe is not well known in Benin nor is it widely used in other African countries. Despite all efforts, aflatoxin contamination continues to be one of the constant threats to food security in Benin.

\section{Implication for Development}

Moulds pose a real threat to food security worldwide. Throughout Africa, mycotoxins are prevalent because the continent is a major producer and consumer of starch-based food crops such as maize. Poor maize preservation techniques increase the risk of contamination by these toxins. In Benin, maize is the main staple of the population and is the most contaminated cereal. Very often, farmers do not get rid of it until the signs of aflatoxin contamination are visible. Serious diseases such as cirrhosis of the liver followed by death and reduced productivity in humans and animals can occur. The ingestion of small amounts of contaminated feed can have two consequences. First, the animal is poisoned and may die or develop serious health complications that are worrisome both for the life of the animal and in terms of the subsequent economic impact on the farmer's income. Second, the aflatoxins present in the animal's body can then be transmitted to any human being through its meat. Due to the lack of storage facilities, farmers sometimes prefer proper drying of their crops in the farms before harvesting, thus increasing the risk of mold attack. Crops contaminated by mold's secondary metabolites don't meet trade and food safety requirements, as many importing countries have set their own criteria. For example, European Union has set new standards on the maximum levels of aflatoxin tolerated in food products (peanuts, copra, palm kernels, cottonseed, corn and derivatives) to $0.02 \mathrm{mg} / \mathrm{kg}$ [72]. European Commission Regulation (EC) No. 1881/2006 sets the maximum aflatoxin level to $4 \mu \mathrm{g} / \mathrm{kg}$ total aflatoxin in products intended for human consumption. In Burkina Faso, the maximum authorized level of total aflatoxins $(\mathrm{B} 1+\mathrm{B} 2+\mathrm{G} 1+\mathrm{G} 2)$ is $15 \mu \mathrm{g} / \mathrm{kg}$. To protect consumers from mycotoxin-related risks, a large number of countries including 15 African countries have legislated on certain mycotoxins including aflatoxins [73] [74]. According to Fellinger [73] and Njobeh et al. [74], the maximum tolerable limits for aflatoxins vary from 5 to $20 \mathrm{ppb}$ for foodstuffs intended for human consumption in Africa and from 5 to $300 \mathrm{ppb}$ for animal foodstuffs. The maximum levels of aflatoxin as set by the Nigerian standards organization are: maize meal (NIS 718: 
2010) max AFB1 2 ppb, sorghum grains (NIS 328: 2003) max level $10 \mathrm{ppb}$; millet grains (NIS 467: 2003) max level $10 \mathrm{ppb}$ and for maize grains NIS 253: 2003 is under revision; $4 \mathrm{ppb}$ for total aflatoxin and $2 \mathrm{ppb}$ for aflatoxin $\mathrm{B} 1$. This same maximum level of total aflatoxin and AFB1 in cereals was also established in Benin by law 09-1984 [75]. According to Neogen [76], losses of US\$670 million have been recorded in Africa. This creates a major obstacle for many agricultural producers to participate in agricultural exchanges and local food procurement initiatives.

\section{Conclusion}

In Benin, several factors favor the contamination of cereals by Aspergillus and the production of aflatoxin. These factors are among others the climatic conditions, plant stress, the cultivation practices, the damage caused by insects and pests, etc. The prevalence followed by the consequences of this contamination is not only very high, but also wreak havoc in the continent on the socio-economic and health level. To overcome various traditional, chemical and biological methods are used, the chemical methods being the most used. These methods have multiple effects both on the environment and on human health, especially children's health. Thus, the sensitization of producers in households on the existence of aflatoxin in maize by insisting on their harmful effects must be carried out in all African countries. Further research needs to be carried out with the use of plant species, such as scopoletin in order to significantly eradicate aflatoxin infection in cereals.

\section{Conflicts of Interest}

The authors declare no conflicts of interest regarding the publication of this paper.

\section{References}

[1] Cardwell, K.F. (2000) Mycotoxin Contamination in Food in Africa: Anti Nutritional Factors. Food and Nutrition Bulletin, 21, 488-493.

[2] Sikirou, R., Nakouzi, S., Adanguidi, J. and Bahama, J. (2018) Reconnaissance des ravageurs du maïs en stockage au Bénin et méthodes de lutte-Fiche technique. FAO, Cotonou.

[3] Allogni, W.N., Coulibaly, O.N., Hell, K. and Mensah, G.A. (2010) Liens entre la contamination des produits maïsicoles à l'aflatoxine et la pauvreté au Bénin. Bulletin de la Recherche Agronomique du Bénin, 68, 40-49.

http://www.slire.net/download/639/article 5 brab 68 allogni et al liens entre la contamination des produits ma sicoles.pdf

[4] Williams, J.H., Phillips, T.D., Jolly, P.E., Stiles, J.K., Jolly, C.M. and Aggarwal, D. (2004) Human Aflatoxicosis in Developing Countries: A Review of Toxicology, Exposure, Potential Health Consequences, and Interventions. The American Journal of Clinical Nutrition, 80, 1106-1122. https://doi.org/10.1093/ajcn/80.5.1106

[5] Wil, C.P. and Gong, Y.Y. (2010) Mycotoxins and Human Disease: A Largely Ig- 
nored Global Health Issue. Carcenogensis, 31, 71-82.

https://doi.org/10.1093/carcin/bgp264

[6] Murphy, P.A., Hendrich, S., Landgren, C. and Bryant, C.M. (2006) Food Mycotoxins: An Update. Journal of Food Science, 71, 51-65.

[7] Dragacci, S., Grosso, F., Bire, R., Fremy, J.M. and Coulon S. (1999) A French Monitoring Programme for Determining Ochratoxin A Occurrence in Pig Kidneys. Natural Toxins, 7, 167-173.

[8] Dieme, E., Fall, R., Sarr, I., Sarr, F., Traore, D. and Seydi, M. (2016) Contamination des céréales par l'aflatoxine en Afrique: Revue des méthodes de lutte existantes. International Journal of Biology and Chemical Sciences, 10, 2285-2299. https://doi.org/10.4314/ijbcs.v10i5.27

[9] Zinedine, A. and Idrissi, L. (2007) Présence et règlementation des mycotoxines dans les aliments aux Maroc: Situation actuelle et perspectives. Les Technologies de Laboratoire, 2, 10-18.

[10] Fandohan, P., Ahouansou, R., Houssou, P., Hell, K., Marasas, W.F.O. and Wingfield, M.J. (2006) Impact of Mechanical Shelling and Dehulling on Fusarium Infection and Fumonisin Contamination in Maize. Food Additives \& Contaminants, 23, 415-421. https://doi.org/10.1080/02652030500442516

[11] Shephard, G.S. (2003) Aflatoxin and Food Safety: Recent African Perspectives. Journal of Toxicology: Toxin Reviews, 22, 267-286. https://doi.org/10.1081/TXR-120024094

[12] Bankole, S.A. and Adebanjo, A. (2003) Mycotoxins in Food in West Africa: Current Situation and Possibilities of Controlling It. African Journal of Biotechnology, 2, 254-263. https://doi.org/10.5897/AJB2003.000-1053

[13] Bankole, M.O., Omemu, A.M. and Adegbesan, A.M. (2006) Maize Cob as a Microbiological Growth Medium for Fungi. ASSET, Series B, 5, 57-64.

[14] Wagacha, J.M. and Muthomi, J.W. (2008) Mycotoxin Problem in Africa Current Status Implications to Food Safety and Health and Possible Management Strategies. International Journal of Food Microbiology, 124, 1-12. https://doi.org/10.1016/j.ijfoodmicro.2008.01.008

[15] Benhalima, H., Chaudhry, M.Q., Mills, K.A. and Price, N.R. (2004) Phosphine Resistance in Stored-Product Insects Collected from Various Grain Storage Facilities in Morocco. Journal of Stored Products Research, 40, 241-249. https://doi.org/10.1016/S0022-474X(03)00012-2

[16] Regnault-Roger, C. (2002) De nouveaux phytoinsecticides pour le troisième millénaire. In: Philogène, B.J.R., Ragnault-Roger, C. and Vincent, C., Biopesticide d’origine végétale, Lavoisier-Editions Tec et Doc, Paris, 19-39.

[17] Center for Disease Control (CDC) (2004) Epidémie d'intoxication par les aflatoxines-provinces orientale et centrale, du Kenya. Morbidity and Mortality Weekly Report, 53, 790-793.

[18] Lewis, L., Onsongo, M., Njapau, H., SchurzRogers, H., Luber, G. and Kieszak, S. (2005) Aflatoxin Contamination of Commercial Maize Products during an Outbreak of Acute Aflatoxicosis in Eastern and Central Kenya. Environmental Health Perspectives, 113, 1763-1767. https://doi.org/10.1289/ehp.7998

[19] Guèye, M.T., Seck, D., Wathelet, J.P. and Lognay, G. (2010) Lutte contre les ravageurs des stocks de céréales et de légumineuses au Sénégal et en Afrique occidentale: synthèse bibliographique. Biotechnology, Agronomy, Society and Environment, 15, 183-194. 
[20] Planetoscope-Statistique (2013) Statistiques mondiales en temps réel sur les céréales. https://www.planetoscope.com/cereales/193-.html

[21] Agricultural Statistics of Benin (2016). http://benin.opendataforafrica.org/emcqbqg/statistiques-agricoles-benin

[22] Office National d'Appui à la Sécurité Alimentaire (ONASA) (2003) Evolution de la campagne agricole et les perspectives alimentaires pour l'an 2003 au Bénin. Vol I et II.

[23] Nago, C.M. (1997) La transformation alimentaire traditionnelle du maïs au Bénin: Détermination des caractéristiques physico-chimiques des variétés en usage; relation avec l'obtention et la qualité des principaux produits dérivés. Thèse de Doctorat, Université Paris-7, Paris.

[24] Baco, M.N. (2019) La place actuelle du maïs dans les exploitations agricoles du Nord-Bénin. Bulletin de la Recherche Agronomique du Bénin (BRAB), 2, 19-30.

http://www.slire.net/download/2534/article 2 complet brab n sp er sr novembr e 2019 baco la place actuelle du ma s.pdf

[25] Adjadi, O., Lokossou, C., Azélokonon, O.G., Bankol, C.D., Djinadou, A.K.A., Ahoyo Adjovi, R.N. and Adjanohoun, A. (2015) Recueil de mets et de boissons à base de maïs consommés au Bénin. INRAB \& PPAAO/WAAPP /Bénin. Dépôt légal No. 7931 du 04 juin 2015, 2ème trimestre, Bibliothèque Nationale $(B N)$ du Bénin, 155 p.

[26] Maboudou, A.G., Adégbola, P.Y., Coulibaly, O., Hell, K. and Amouzou, M.E. (2004) Factors Affecting the Use of Improved Clay Store for Maize Storage in the Central and Northern Benin. Bulletin de la Recherche Agronomique du Bénin-Numéro spécial 2: Aspects économiques du stockage et de la conservation du maïs au Sud-Bénin, 2, 1-12.

[27] Fandohan, B., Assogbadjo, A.E., Glele Kakaï, R., Kyndt, T. and Sinsin, B. (2011) Quantitative Morphological Descriptors Confirm Traditionally Classified Morphotypes of Tamarindus indica L. Fruits. Genetics Resources and Crop Evolution, 58, 299-309. https://doi.org/10.1007/s10722-010-9575-3

[28] Programme d’Appui au Développement du Secteur Agricole (PADSA) (2000) Évaluation à mi-parcours du PADSA. Rapport final. PADSA/DANIDA, Cotonou.

[29] Affognon, H., Kossou, D. and Bell, A. (2000) Développement Participatif de Technologies Post-Récolte au Bénin. Expérience du Projet Pilote de Lutte Intégrée contre le Grand Capucin du Maïs dans le Système Post-Récolte des Paysans, 49 p.

[30] Gauthier, A. (2016) Les mycotoxines dans l'alimentation et leur incidence sur la santé. Sciences pharmaceutiques. dumas-01315198.

[31] Organisation Mondiale de la Santé (OMS) (2018) Les aflatoxines. Note de sécurité sanitaire des aliments.

[32] Mannon, J. and Johnson, E. (1985) Fungi down on the Farm. New Scientist, 195, 12-16.

[33] American Academy of Pediatrics (AAP) (1998) Toxic Effects of Indoor Moulds. Committee on Environmental Health. Pediatrics, 101, 712-714.

https://doi.org/10.1542/peds.101.4.712

[34] Miller, J.D. (1995) Mycotoxins. In: Cardwell K.F., Ed., Proceedings of the Workshop on Mycotoxins in Food in Africa, International Institute of Tropical Agriculture, Cotonou, 18-22.

[35] Allomasso, R., Coulibaly, R., Glitho, O.I. and Hell, K. (2006) Principaux facteurs affectant l'état nutritionnel et de santé des enfants exposés à l'aflatoxine au Bénin: Application du model Probit. Bulletin de recherche agronomique du Bénin, No. 53, 
9-17.

[36] Wild, C.M. (1996) Compte rendu de l'atelier de coordination sur les mycotoxines et les aliments en Afrique, organisé du 6 au 10 novembre 1995 en République du Bénin. Institut International d'Agriculture Tropicale, Division Phytiatrie.

[37] FAO (2014) Systèmes Appropriés de Stockage des Semences et des Grains pour les Agriculteurs à Petite Échelle: Pratiques clés pour les praticiens de la RRC.

[38] MINADER (2013) Liste des pesticides homologues au Cameroun au 31 juillet 2013.

[39] Bata, A. and Lasztity, R. (1999) Detoxification of Mycotoxin-Contaminated Food and Feed by Microorganisms. Trends in Food Science and Technology, 10, 223-228. https://doi.org/10.1016/S0924-2244(99)00050-3

[40] Ogiehor, I.S. and Ikenebomeh, M.J. (2004) Antimicrobial Effects of Sodium Benzoate on the Growth, Survival and Aflatoxin Production Potential of Some Species of Aspergillus in Garri during Storage. Pakistan Journal of Nutrition, 3, 300-303. https://doi.org/10.3923/pjn.2004.300.303

[41] Gowda, N.K.S., Malathi, V. and Suganthi, R.U. (2004) Effect of Some Chemical and Herbal Compounds on Growth of Aspergillus parasiticus and Aflatoxin Production. Animal Feed Science and Technology, 116, 281-291. https://doi.org/10.1016/j.anifeedsci.2004.02.008

[42] Kumar, R. (1991) La lutte contre les insectes ravageurs: L'agriculture en régions tropicales. Wageningen, Paris.

[43] Lienard, V. and Seck, D. (1994) Revue des méthodes de lutte contre Callobruchus maculatus (F.) (Coleoptera: Bruchidae), ravageur des graines de niébé (Vigna unguiculata (L.) Walp) en Afrique tropicale. International Journal of Tropical Insect Science, 15, 301-311. https://doi.org/10.1017/S1742758400017616

[44] Adjalian, E., Noudogbessi, J.P., Kossou, D. and Sohounhloue, D. (2014) État et perspectives de lutte contre Sitotroga cerealella (Olivier, 1789), déprédateur des céréales au Bénin: Synthèse bibliographique. Journal of Applied Biosciences, 79, 6955-6967. https://doi.org/10.4314/jab.v79i1.16

[45] Igawa, T., Takahashi-Ando, N., Ochiai, N., Ohsato, S., Shimizu, T., Kudo, T., Yamaguchi, I. and Kimura, M. (2007) Reduced Contamination by the Fusarium Mycotoxin Zearalenone in Maize Kernels through Genetic Modification with a Detoxification Gene. Applied and Environmental Microbiology, 73, 1622-1629.

[46] Busani, B. (2016) Afrique: Les Aflatoxines Minent La Santé et Le Commerce Dans La Partie Subsaharienne. ReliefWeb.

http://ipsnews.net/francais/2016/01/04/afrique-les-aflatoxines-minent-la-sante-et-le -commerce-dans-la-partie-subsaharienne/

[47] Gansou, G., Yabi, M. and Kiki, E. (2000) Etude des modes de «vente à terme» et de «vente précoce» des récoltes du maïs par les producteurs. PADSA/DANIDA, Cotonou, $43 \mathrm{p}$.

[48] Rahimi, E., Bonyadian, M., Afei, M. and Kazemeini, H.R. (2010) Occurrence of Aflatoxin M1 in Raw Milk of Five Dairy Species in Ahvaz, Iran. Food and Chemical Toxicology, 48, 129-131. https://doi.org/10.1016/j.fct.2009.09.028

[49] Bhat, R.V. and Vasanthi, S. (2003) Mycotoxin Food Safety Risks in Developing Countries. Food Safety in Food Security and Food Trade. Vision 2020 for Food, Agriculture and Environment, Focus 10, brief 3 of 17. 1-2.

[50] Gong, Y.Y., Egal, S., Hounsa, A., Turner, P.C., Hall, A.J. and Cardwell, K.F. (2003) Determinants of Aflatoxin Exposure in Young Children from Benin and Togo, West Africa: The Critical Role of Weaning. International Journal of Epidemiology, 
32, 556-562. https://doi.org/10.1093/ije/dyg109

[51] Gong, Y.Y., Cardwel, L.K., Hounsa, A., Egal, S., Turner, P.C., Hall, A.J. and Wild, C.P. (2002) Exposition à l'aflatoxine alimentaire et la croissance avec facultés affaiblies chez les enfants du Bénin et du Togo: Étude transversale. British Medical Journal, 325, 20-21. https://doi.org/10.1136/bmj.325.7354.20

[52] Obade, M.I., Andang'o, P., Obonyo, C. and Lusweti, F. (2015) Exposure of Children 4 to 6 Months of Age to Aflatoxin in Kisumu Country, Kenya. African Journal of Food, Agriculture, Nutrition and Developpement, 15, 9949-9963.

[53] Benkerroum, N. (2020) Aflatoxins: Producing-Molds, Structure, Health Issues and Incidence in Southeast Asian and Sub-Saharan African Countries. International Journal of Environmental Research and Public Health, 17, 1215.

https://doi.org/10.3390/ijerph17041215

[54] Krishnamachari, K.A.V., Bhat, R.V., Nagarajan, V. and Tilak, T.B.G. (1975) Hepatitis Due to Aflatoxicosis: An Outbreak in Western India. The Lancet, 305, 1061-1063. https://doi.org/10.1016/S0140-6736(75)91829-2

[55] Wilson, D.M., Mubatanhema, W. and Jurjevic, Z. (2002) Biology and Ecology of Mycotoxigenic: Aspergillus Species as Related to Economic and Health Concerns. In: DeVries, J.W., Trucksess, M.W. and Jackson, L.S., Eds., Mycotoxins and Food Safety, Springer, Boston, 3-17. https://doi.org/10.1007/978-1-4615-0629-4 2

[56] Ito, Y., Peterson, S.W., Wicklow, D.T. and Goto, T. (2001) Aspergillus pseudotamarii, a New Aflatoxin Producing Species in Aspergillus Section Flavi. Mycological Research, 105, 233-239. https://doi.org/10.1017/S0953756200003385

[57] PACA (2013) Effet de l'aflatoxine sur l'agriculture, le commerce et la santé.

[58] Mayer, C.F. (1953) Endemic Panmyelotoxicoses in the Russian Grain Belt. Part One: The Clinical Aspects of Alimentary Toxic Aleukia (ATA), a Comprehensive Review. The Military Surgeon, 113, 173-189. https://doi.org/10.1093/milmed/113.3.173

[59] Coker, R.D. (1997) Mycotoxins and Their Control: Constraints and Opportunities. NRI Bulletin 73. Natural Resources Institute, Chatham.

[60] Munyaradzi, M. (2011) La sensibilisation comme méthode de lutte contre les aflatoxines. SciDev.Net.

https://www.scidev.net/afrique-sub-saharienne/news/la-sensibilisation-comme-m-t hode-de-lutte-contre-les-aflatoxines

[61] Ahmed, N.E., Abdalla, A.E., Adam, Y.S. and Betjowck. (2009) Fungi and Mycotoxins Associated with Sorghum Grains in Major Storage Systems in Gedarif, Sudan. A Paper Submitted to the 17th Board of Directors Meeting of the National Council for Mycotoxins, December 2009. Sudanese Standards and Measurements Organisation, Sudan.

[62] Anjorin, S.T., Makun, H.A. and Iheneacho, H.E. (2008) Effect of Lippia multiflora Leaf Extract and Aspergillus flavus on Germination and Vigour Indices of Sorghum bicolor (Moench). International Journal of Tropical Agriculture and Food Systems, 2, 130-134. https://doi.org/10.4314/ijotafs.v2i2.40973

[63] Chulze, S.N. (2010) Les stratégies visant à réduire les niveaux de mycotoxines dans le maïs pendant le stockage: A Review. Food Additives and Contaminants, 27, 651-657. https://doi.org/10.1080/19440040903573032

[64] Ba, R., Monteiro, N.M.F., Koudjega, H., Adjagbo, C., Kohoude, J., Djinadou Igue, F., Gbaguidi, F., Mensah, G.A. and Baba Moussa, L. (2015) Synthèse bibliographique sur l'utilisation de la scopolétine pour la réduction des aflatoxines du maïs en 
stock au bénin. Annales des Sciences Agronomiques, 19, 201-211.

[65] Gnonlonfin, B.J.G., Adjovi, Y., Gbenou, J., Gbaguidi, F., Brimer, L. and Sanni, A. (2011) Scopoletin in Cassava Products as an Inhibitor of Aflatoxin Production. Journal of Food Safety, 9, 553-558. https://doi.org/10.1111/j.1745-4565.2011.00334.x

[66] Wang, G.L., Tian, J.G. and Chen, D.C. (1997) Study on Chemical Composition of Rubia cordifolia L. and R. Tinctorum L. II. Quantitative Determination of Alizarin and Lucidin by Reversedphase HPLC. Journal of Pharmaceutical Analysis, 17, 219-221.

[67] Menkir, A., Brown, R.L., Bandyopadhyay, R., Chen, Z.Y. and Cleveland, T.E. (2006) A USA-Africa Collaborative Strategy for Identifying, Characterizing, and Developing Maize Germplasm with Resistance to Aflatoxin Contamination. Mycopathologia, 162, 225-232. https://doi.org/10.1007/s11046-006-0056-3

[68] Okun, D.O., Khamis, F.M., Muluvi, G.M., Ngeranwa1, J.J., Ombura, F.O., Yongo, M.O. and Eucharia, U. (2015) Distribution of Indigenous Strains of Atoxigenic and Toxigenic Aspergillus flavus and Aspergillus parasiticus in Maize and Peanuts Agro-Ecological Zones of Kenya. Agriculture \& Food Security, 4, Article No. 14. https://doi.org/10.1186/s40066-015-0033-5

[69] Chebon, S., Wanyoike, W., Bii, C., Gathumbi, J. and Ogoyi, D. (2016) Incidence of Aflatoxigenic Fungi and Aflatoxins in Maize Cultivated in Highland and Midaltitude Agro-Ecological Zones in Kenya. Journal of Scientific Research Reports, 9, 1-12.

[70] IITA (International Institute of Tropical Agriculture) (2010) Making Kenyan Maize Safe from Deadly Aflatoxins.

[71] Marechera, G. and Ndwiga, J. (2012) Estimation of the Potential Adoption of Aflasafe among Smallholder Maize Farmers in Lower Eastern Kenya. African Journal of Agricultural and Resource Economics, 10, 72-85.

[72] Leszkowicz, A. (2003) Les mycotoxines condition de formation, effet sur la santé et évaluation des risques. Présentation ENSA, Toulouse.

[73] Fellinger, A. (2006) Worldwide Mycotoxin Regulations and Analytical Challenges. Proceedings of the World Grain Summit. Foods and Beverages, San Francisco, 17-20 September 2006, 19-23.

[74] Njobeh, B.P., Dutton, F.M. and Makun, H.A. (2010) Mycotoxins and Human Health: Significance, Prevention and Control. In Ajay, K.M., Ashutosh, T., Shivani, B.M., Eds., Smart Biomolecules in Medicine, VBRI Press, New Delhi, 132-177.

[75] ECOWAS (2015) Etude exploratoire pour l'évaluation de l'environnement politique et des capacités techniques pour le contrôle des aflatoxines dans les états membres de la CEDEAO.

[76] World Bank Group (2016) Rapport Final sur la Chaîne de Valeur du Maïs. http://pubdocs.worldbank.org/en/355871598894160953/TF0A2928-Maize-Value-C hain-and-Aflatoxin-Final-Report-FR-FINAL-JTF.pdf 